\title{
Durability of Geopolymer Concrete with Scrap Steel Slag Coarse Aggregate
}

\author{
Suganya N., Thirugnanasambandam S. T.
}

\begin{abstract}
Use of environmental friendly materials in concrete to make concrete sustainable is gaining importance, as the growth of the construction sector is rapid and massive in India. Such a sustainable concrete is the geopolymer concrete with scrap steel slag coarse aggregate. The concrete replaces cement and natural coarse aggregate by fly ash and scrap steel slag. Mechanical Strength of the concrete of M20 grade was evaluated and found suitable. Concrete strength has no role without the concrete being durable. Experimental tests were carried out to check the durability of the concrete and the results are presented in this paper. M20 grade geopolymer concrete with scrap steel slag coarse aggregate was tested after ambient curing for 28 days and the results are compared with M20 grade cement concrete with conventional Coarse aggregate. Durability was checked based on Water absorption, Acid resistance, Sulphate resistance and Sorptivity. The experimental results indicate that geopolymer concrete exhibit excellent durability than conventional cement concrete.
\end{abstract}

Keywords: Durability, Short - term, Geopolymer, Ambient Curing, Scrap Steel Slag Coarse Aggregate.

\section{INTRODUCTION}

The degree of durability of concrete required depends mainly upon the environment of their exposure. The ingredients of concrete, manufacturing process and their interaction with the exposed environmental elements determine the durable life of any concrete. Durability is the main property of the concrete besides its mechanical properties. Geopolymer concrete conserves the use of natural resources by replacing cement by flyash. This experimental work evaluates the short-term durability performance of geopolymer concrete made with class $\mathrm{F}$ type flyash and GGBS as binder. Scrap steel slag, slag obtained as by-product from steel re-rolling mill was used as coarse aggregate. The addition of GGBS in concrete aids the concrete to be cured under ambient conditions.

This paper presents the short-term durability report on the geopolymer concrete with scrap steel slag coarse aggregate. First the scrap steel slag was checked for its soundness, $\mathrm{pH}$ and Alkali Aggregate Reactivity as a measure of its durability and then used in making concrete. Then the concrete at the age of 28days was tested for its compressive strength, water absorption, sorptivity, acid resistance and sulphate resistance. Due to time constrains only the short-term durability properties of the concrete was studied and the results was compared with the same grade cement concrete with conventional coarse aggregate.

Revised Manuscript Received on February 05, 2020.

* Correspondence Author

Suganya N.*, Research Scholar, Department of Civil \& Structural Engineering, Annamalai University, Tamil Nadu, India.

Dr. Thirugnanasambandam S., Professor, Department of Civil \& Structural Engineering, Annamalai University, Tamil Nadu, India.

(C) The Authors. Published by Blue Eyes Intelligence Engineering and Sciences Publication (BEIESP). This is an open access article under the CC BY-NC-ND license (http://creativecommons.org/licenses/by-nc-nd/4.0/)

\section{LITERATURE REVIEW}

Monita Olivia and Hamid R. Nikraz ${ }^{(1)}$ reports that the water absorption of geopolymer concrete is less than $5 \%$. Water absorption can be reduced by decreasing the water-solid ratio, increasing the alkaline-fly ash ratio and increasing the aggregate-solids ratio. Permeable voids were less than $12 \%$. The void content of geopolymer concrete varies from $8.2 \%$ to $13 \%$. The alkaline to fly ash ratio of 0.3 reduced porosity of concrete. Though aggregate to binder ratio of 3.5 gave higher strength, it has to be increased to 4.7 to achieve low porosity.

Sreevidya et al ${ }^{(2)}$ evaluated the acid resistance of fly ash based geopolymer mortar specimens. Ratio of alkali activator solution to fly ash was varied as $0.376,0.386,0.396$ and 0.416. Both hot cured specimens @ $60^{\circ} \mathrm{C}$ for 24 hours and ambient cured specimens were taken for study. Specimens were immersed in 5\% sulphuric acid and 5\% hydrochloric acid for 14 weeks and their performance was assessed on the basis of change in weight and compressive strength. The samples suffered very little weight change and the reduction in compressive strength was similar to that of the strength loss of cement concrete mortar.

Aradhana Mehta and Kuldeep Kumar (3) studied the durability of geopolymer concrete and reports that geopolymer is highly acid resistant. After 28 days of sulphuric acid exposure under $2 \%, 4 \%$ and $6 \%$ concentration, the geopolymer specimens were found without any significant change in shape and mass.

Whereas cement concrete under same conditions suffered surface damage and noticeable bulging.

Bapugouda patil et al (4) studied the durability of geopolymer concrete under acid test, chloride test, sulphate test, fire resistance test and water absorption test. The test report shows that very minute change was observed in acid test. Weight gain was more compared to control concrete for geopolymer under $\mathrm{NaCl}$ and $\mathrm{MgSO}_{4}$. Geopolymer was less porous and absorbed $10.9 \%$ less water than control concrete. Geopolymer exhibited excellent fire resistance at $300^{\circ} \mathrm{C}$ and $600^{\circ} \mathrm{C}$.

\section{MIX DESIGN}

\section{A.Cement Concrete}

Conventional mix for cement concrete of grade M20 was arrived according to IS 10262- 2009. Table I represents the mix design of M20 grade cement concrete. 


\section{Durability of Geopolymer Concrete with Scrap Steel Slag Coarse Aggregate}

Table I - M20 Grade Cement Concrete.

\begin{tabular}{|c|l|c|}
\hline S.No. & Ingredients & $\mathbf{k g} / \mathbf{m}^{\mathbf{3}}$ \\
\hline 1 & Cement & 311 \\
\hline 2 & GGBS & - \\
\hline 3 & Water & 140 \\
\hline 4 & Fine Aggregate & 727 \\
\hline 5 & Coarse Aggregate (Conventional) & 1267 \\
\hline 6 & Chemical admixture & 6.22 \\
\hline 7 & W/C ratio & 0.45 \\
\hline
\end{tabular}

\section{B. Geopolymer Concrete}

Geopolymer concrete mix for M20 grade was arrived based on the cement concrete mix. Variables of the mix design were fixed based on the previous literatures. The following are the constant values used for variables in the mix design.

- Fly Ash to GGBS ratio = $\quad 70: 30$

- Activator solution to binder ratio= 0.45

- Molarity of $\mathrm{NaOH}=8 \mathrm{M}$

- Sodium hydroxide to Sodium silicate ratio $=2.5$

Table II represents the mix design of M20 grade geopolymer concrete.

Table II - M20 Grade Geopolymer Concrete.

\begin{tabular}{|c|l|c|}
\hline S. No. & \multicolumn{1}{|c|}{ Ingredients } & $\mathbf{k g} / \mathbf{m}^{\mathbf{3}}$ \\
\hline 1 & Fly Ash & 218 \\
\hline 2 & GGBS & 93 \\
\hline 3 & Activator solution & 140 \\
\hline 3 & Sodium Hydroxide solution & 40 \\
\hline 4 & Sodium silicate solution & 100 \\
\hline 5 & Fine Aggregate & 727 \\
\hline 6 & Scrap Steel slag Coarse aggregate & 1038 \\
\hline 7 & Chemical admixture & 6.22 \\
\hline
\end{tabular}

\section{DURABILITY TEST ON SCRAP STEEL SLAG}

Tests on scrap steel slag followed standard procedures recommended by the codes and the results are reported in Table III.

Table III - Tests on Scrap Steel Slag

\begin{tabular}{|c|l|c|}
\hline $\begin{array}{c}\text { S. } \\
\text { No }\end{array}$ & \multicolumn{1}{|c|}{ Description } & \multicolumn{1}{c|}{ Result } \\
\hline 1 & Water Absorption & $1.5 \%$ by weight \\
\hline 2 & pH value & 7.91 \\
\hline & $\begin{array}{l}\text { Alkali aggregate } \\
\text { reactivity (a) Red } \\
\text { uction in alkalinity of } \\
1.0 \mathrm{~N} \mathrm{NaOH}\end{array}$ & $\begin{array}{l}\text { (b) Silica } \\
\text { dissolved }\end{array}$ \\
\hline 4 & $\begin{array}{l}\text { Soundness(after 5 } \\
\text { cycles) (a) Sodi } \\
\text { um sulphate }\end{array}$ & 110.00 millimoles /tr \\
\hline
\end{tabular}

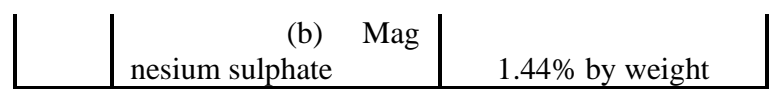

\section{V.CASTING AND TESTING CONCRETE}

\section{A.Casting and Curing of Specimens}

Both cement concrete and geopolymer concrete specimens were cast using the same standard procedure. The ingredients were batched and the dry materials were mixed first. The liquid component was then added to the dry mix and mixing was continued until arriving at a cohesive concrete mass. Concrete cubes of size 150 x 150 x $150 \mathrm{~mm}$ were cast to study compressive strength, acid resistance and sulphate resistance. Concrete cylinders of size $100 \mathrm{~mm}$ dia and $50 \mathrm{~mm}$ height were cast to study sorptivity. Specimens one day after casting were demoulded and cured for 28 days. Cement concrete specimens were water cured and geopolymer concrete specimens were ambient cured.

\section{B. Compressive Strength}

Compressive strength was tested using standard procedure in the compression testing machine. The compressive strength of cement concrete was found 27.67 MPa and geopolymer concrete was 29.11 Mpa.

\section{C.Water Absorption}

Concrete specimens were dried in oven for not less than 24 hours under elevated temperature of $100^{\circ} \mathrm{C}$ to $110^{\circ} \mathrm{C}$. Specimens were then removed and allowed to air dry under room temperature. The dried samples were weighed and then immersed in water. Wet weight was recorded at every $1 / 2$ hour interval upto $2 \frac{1}{2}$ hours and then at 1 hour interval upto 4 hours. Final weights of immersed cubes were recorded at 24 and 72 hours. Test was performed in accordance with ASTM C $642-13$ and the water absorption was calculated using formula (1)

$\mathrm{W}_{\mathrm{ab}}=\left(\left(\mathrm{W}_{\mathrm{s}}-\mathrm{W}_{\mathrm{d}}\right) / \mathrm{W}_{\mathrm{d}}\right) \times 100 \%$

Where,

$\mathrm{W}_{\mathrm{ab}}=$ Saturated water absorption in \%

$\mathrm{W}_{\mathrm{s}}=$ Weight of fully saturated specimen in $\mathrm{kg}$.

$\mathrm{W}_{\mathrm{d}}=$ Weight of oven dried specimen in $\mathrm{kg}$

\section{D.Acid Resistance}

Acid resistance of concrete specimens was tested by exposing them to Concentrated Sulphuric acid. $150 \mathrm{~mm}$ concrete cubes of cement concrete and geopolymer concrete after their curing period were immersed in $1 \% \mathrm{H}_{2} \mathrm{SO}_{4}$. The specimens were left in acid for 30 days. Periodically, the acid was checked and refreshed. After required days in acid, the specimens were removed, wiped, weighed and then put to compressive strength test under Compression Testing Machine.

\section{E. Sulphate Resistance}

For observing the resistance to sulphate attack, $5 \%$ of sodium sulphate with $99 \%$ purity was dissolved in water to make required amount of sulphate solution to immerse the specimens completely in water.

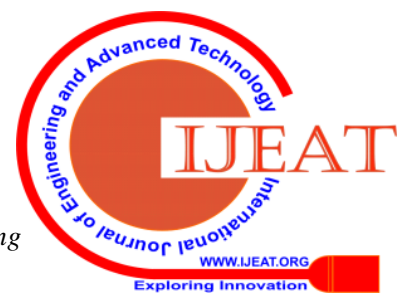


The specimens after curing were immersed in the solution for a period of 30 days. Solution was checked and refreshed periodically. The specimens were then taken out, cleaned, dried and weighed. Then, the compressive strength of the specimens was recorded.

\section{F. Sorptivity}

Sorptivity of concrete is its tendency to absorb and transmit water by capillarity through its pores. The specimens were dried in oven at $100^{\circ} \mathrm{C}$ and then cooled at room temperature and weighed. The periphery of the cylinder was given a non absorbent coat to prevent absorption of water when drowned. Then the specimens were drowned in water such that the water level is at $5 \mathrm{~mm}$ height from the base of the specimen. The quantity of water absorbed after 30 minutes was recorded by measuring the weight of the specimen. Sorptivity was calculated with the formula (2)

$$
\mathrm{S}=\mathrm{I} / \mathrm{t}^{1 / 2}
$$

Where,

$$
\mathrm{I}=\left(\mathrm{W}_{2}-\mathrm{W}_{1}\right) /(\mathrm{Axd})
$$

$\mathrm{W}_{1}=$ Oven dry weight of cylinder in $\mathrm{g}$.

$\mathrm{W}_{2}=$ Weight of cylinder after 30 minutes of capillary suction in $\mathrm{g}$.

$\mathrm{A}=$ Water penetration surface area in $\mathrm{mm}^{2}$.

$\mathrm{d}=$ Density of water in $\mathrm{g} / \mathrm{mm}^{3}$.

$\mathrm{S}=$ Sorptivity in $\mathrm{mm}$.

$\mathrm{t}=$ Time taken in minutes.

\section{RESULTS AND DISCUSSION}

Results from Table III indicate that the water absorption, soundness and alkali aggregate reaction values of scrap steel slag are all within code limits.

Weight loss after exposure to Sodium sulphate and Magnesium sulphate was $1.2 \%$ and $1.44 \%$ against the limit of $12 \%$ and $18 \%$ as per IS $383: 2016$.

The values of alkali aggregate reactivity reported falls under innocuous aggregate conducted as per IS 2386:1963 (VII). The scrap steel slag coarse aggregate do not indicate potential deleterious degree of alkali aggregate reactivity.

The experimental test results reported in Table IV indicate that the durability performance of geopolymer concrete with scrap steel slag coarse aggregate is superior to conventional cement concrete.

\begin{tabular}{|c|c|c|c|}
\hline $\begin{array}{l}\text { S. } \\
\text { No }\end{array}$ & $\begin{array}{c}\text { Parameter of } \\
\text { Study }\end{array}$ & M20CC & M20GC \\
\hline 1 & $\begin{array}{l}\text { Compressive } \\
\text { Strength, MPa }\end{array}$ & 27.67 & 29.11 \\
\hline 2 & $\begin{array}{l}\text { Saturated Water } \\
\text { Absorption }\end{array}$ & $2.9 \%$ & $3.2 \%$ \\
\hline 3 & $\begin{array}{l}\text { Reduction in } \\
\text { Compressive } \\
\text { Strength after Acid } \\
\text { Attack }\end{array}$ & $9 \%$ & $0.8 \%$ \\
\hline 4 & $\begin{array}{l}\text { Reduction in } \\
\text { Compressive } \\
\text { Strength after } \\
\text { Sulphate Attack }\end{array}$ & $8.7 \%$ & $0.5 \%$ \\
\hline
\end{tabular}

Table IV - Test Results

0.13954715

0.11628929

The compressive strength of geopolymer concrete with scrap steel slag coarse aggregate is $5 \%$ higher than conventional concrete. Saturated water absorption for steel slag concrete is $0.3 \%$ higher than cement concrete. But still less than $5 \%$ limit, so it may not affect is performance. Geopolymer concrete exhibit excellent resistance to acid and sulphate attack. The reduction in compressive strength after 30 days of exposure in acid and sulphate are only $0.8 \%$ and $0.5 \%$ respectively. Sorptivity of geopolymer concrete was in the rate of $0.11628929 \mathrm{~mm} / \mathrm{min}^{0.5}$, which is less than that of the conventional cement concrete.

\section{CONCLUSION}

From the experimental results it is clear that the geopolymer concrete is superior in durability performance when compared to cement concrete. The presence of scrap steel slag coarse aggregate was not found to affect its durability performance. Hence geopolymer concrete with scrap steel slag coarse aggregate is durable to be used in construction.

\section{ACKNOWLEDGMENT}

The research project under the title Development of Geopolymer concrete and testing of elements (MRP MAJOR - CIVIL - 2013-36977) sanctioned by UGC to Annamalai University, helpful in carrying this research work is thankfully acknowledged by the authors.

\section{REFERENCES}

1. Monita Olivia and Hamid R. Nikraz (2011), Strength and Water Penetrability of Fly Ash Geopolymer concrete, ARPN Journal of Engineering and Applied Sciences, Vol.6, No.7.

2. Sreevidya V, Anuradha R, Dinakar. D and Venkatasubramani. R (2012), Acid Resistance of Geopolymer Mortar under Ambient Curing and Heat Curing, International Journal of Engineering Science and Technology.

3. Dr. Aradhana Mehta and Kuldeep Kumar (2016), Strength and Durability Characteristics of Fly Ash and Slag Based Geopolymer Concrete, International Journal of Civil Engineering and Technology, Vol.7, Issue 5, pp. $305-314$

4. Bapugouda Patil, Veerendra Kumar. M and H. Narendra (2015), Durability Studies on Sustainable Geopolymer Concrete, International Research Journal of Engineering and Technology, Vol.2, Issue 4. 